\title{
Giant Placental Chorioangioma with Intrauterine Fetal Death
}

\author{
Hansa Dhar ${ }^{1}$ \\ 'Department of obstetrics and gynecology, Nizwa Regional Referral Hospital, Sultanate of Oman.
}

\section{ABSTRACT}

Chorioangioma of the placenta is a common benign vascular tumour of the placenta consisting of blood vessels and stroma. Most of these tumours are small and have no adverse impact on the fetus. Large tumours are associated with complications affecting mother and the fetus which may cause intrauterine fetal death. Chorioangiomas probably act as peripheral shunts between arteries and veins (arteriovenous shunts) leading to progressive heart failure of the fetus. Prenatal diagnosis is achieved by ultrasonography and Doppler studies will confirm the highly vascular nature of the mass. As the tumour is associated with unfavourable effects on the mother and fetus like polyhydramnios, prematurity, toxaemia, hydrops and fetal heart failure pregnancy needs to have regular surveillance to detect and manage complications early. A case of giant placental chorioangioma in a primigravida associated with intrauterine fetal death at 30 weeks of gestation is reported.

Keywords: Chorioangioma, hydrops fetalis; intrauterine fetal death; placental tumors.

\section{INTRODUCTION}

Giant placental chorioangioma are associated with a high prevalence of pregnancy complications and a poor perinatal outcome. ${ }^{1}$ The tumour may be located accidentally during routine antenatal scan. The sonographic appearance of a chorioangioma is that of a solid or complex mass on the fetal surface of the placenta .Mostly located underneath the chorionic plate near the insertion of the umbilical cord and often protruding into the amniotic cavity. ${ }^{2}$ Three histological patterns of chorioangiomas described in literature are angiomatous, cellular and degenerate. The angiomatous is the most common with numerous small areas of endothelial tissue, capillaries and blood vessels surrounded by placental stroma. The cellular pattern has abundant endothelial cells within a loose stroma. The degenerate pattern has calcification, necrosis or hyalinization. ${ }^{3}$

\section{CASE REPORT}

Twenty seven years primigravida was admitted with history of vaginal bleeding at 25 weeks in Nizwa referral hospital. A routine ultrasound examination revealed a live fetus with normal liquor estimation. No fetal structural anomalies were detected and there was no evidence of hydrops fetalis. Placenta was in the upper anterior segment and a large, subchorionic, well circumscribed mass, hypoechoiec measuring $5.97 \mathrm{~cm} \times 8.55 \mathrm{~cm}$ was observed protruding into the amniotic cavity.This

Correspondence: Dr. Hansa Dhar, Department of obstetrics and gynecology, Nizwa Regional Referral Hospital, Sultanate of Oman. Email: hansad2009@gmail.com, Phone: +968-92955360. 
mass was arising from the fetal surface of the placenta, marginally placed, with different echogenicity from the rest of the placenta. Color Doppler was consistent with a highly vascularized mass. An impression of placental tumour (haemangioma) was made (Figure 1).

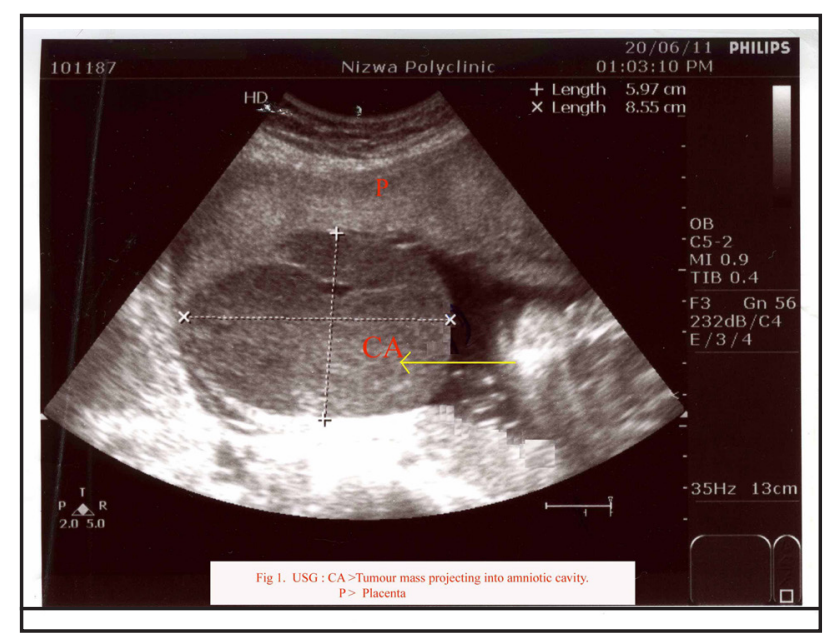

Figure 1. Ultrasound imaging showing placental mass protruding into the amniotic cavity.

She was vitally stable with blood pressure $120 / 70 \mathrm{mmHg}$, pulse 80 beats/minute, and respiratory rate 18 breaths/ minute. Her investigations showed VDRL non-reactive, sickling negative, blood group O Rh positive, $\mathrm{Hb} 11.4 \mathrm{~g} /$ $\mathrm{dl}$ and platelets $231 \mathrm{~K} / \mathrm{ul}$.Coagulation profile, renal and liver function tests were within normal limits. No history of diabetes or hypertension was noted. She was admitted for rest and further evaluation of this mass. She received dexamethasone for improvement of fetal lung maturity. Patient remained vitally stable during her stay in the hospital with no complaints of vaginal bleeding. Thereafter she followed in the outpatient department in the high risk pregnancy clinic. Follow up ultrasound and umbilical artery Doppler studies were normal. At 30 weeks she reported to accident and emergency department with increasing labour pains and history of loss of fetal movements since three days. Ultrasound examination confirmed intrauterine fetal death with mild fetal hydrops. Placental examination revealed the same hypoechoic mass with the same measurements. On examination she was in active labour with cervical dilatation of $3 \mathrm{~cm}$ and bulging membranes. She laboured for five hours and delivered a macerated still birth male fetus of $1100 \mathrm{gms}$. No obvious fetal anomaly was noted. Placenta and the mass with membranes delivered after 20 minutes as the cord got severed during the expulsion of this large placental mass. Placenta and the mass together weighed 1100 gms. The mass weighed 600 gms whereas the placenta weighed lesser, $500 \mathrm{gms}$. The mass was purplish red in colour with glistening, bosselated outer surface, soft and spongy in consistency (Figure 2). The specimen was sent for histopathologic examination. Her postnatal period was uneventful. She was discharged two days later and follow up checkup two weeks later was unremarkable.

The histopathological report was released as:

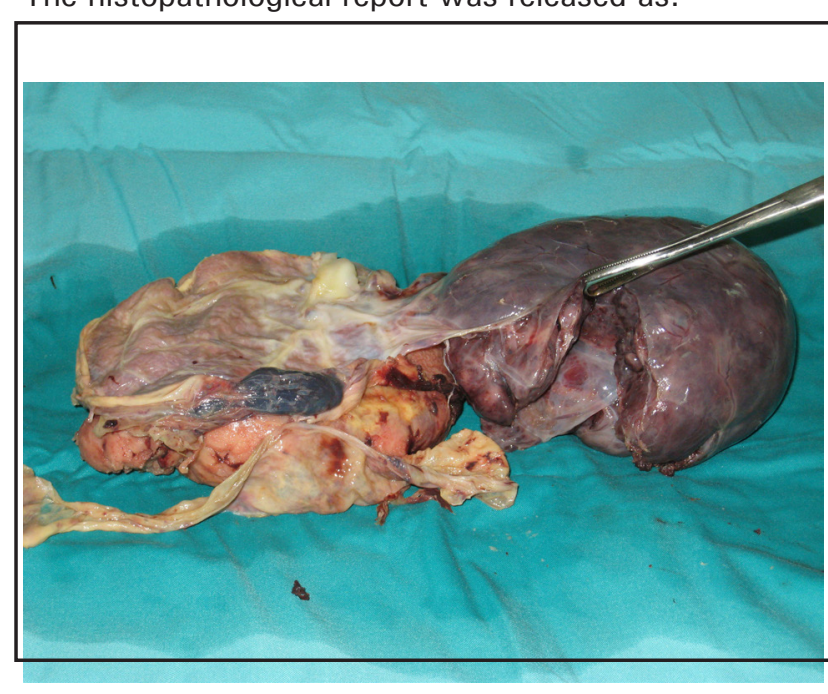

Figure 2. Chorioangioma attached to the fetal surface of the placenta.

Gross: Placenta weighing 1100 grams measures $17 \times 12 \times 3 \mathrm{~cm}^{3}$ with an attached soft tissue mass measuring $12 \times 11.5 .5 \mathrm{~cm}^{3}$. The cut section of the mass appears dark brown. Only a stump of cord is attached to the fetal surface of the placenta.The membranes appear unremarkable. The cut section of the placental disc appears unremarkable.

Microscopy: Sections show a neoplasm comprising proliferation of capillary sized and occasional cavernous vessels surrounded by connective tissue stroma. Umbilical cord shows three blood vessels with thickening of the intima. Focal squamous metaplasia of the surface amnion of the cord is noted. Sections from the membranes show chorioamnionitis. Placental disc shows chorionic villi with no syncytial knots and fibrosis. Histopathology confirmed the diagnosis of placental chorioangioma in this case (Figure 3). 


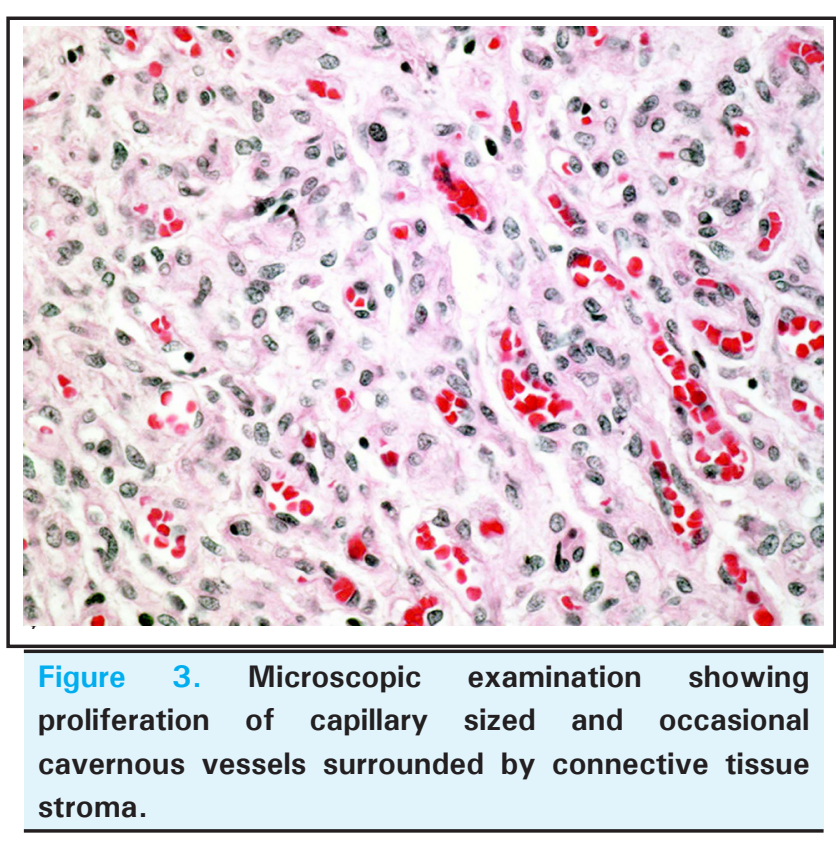

\section{DISCUSSION}

Chorioangioma is the most common benign tumour of the placenta and is thought to be either an angioma or hamartoma derived from primitive chorionic mesenchyme. ${ }^{4}$ Majority are single, small, encapsulated, intraplacental vascular tumours. Ghourab, ${ }^{5}$ reported that vascular hypoechogenic tumours are associated with higher incidence of pregnancy complications as compared to avascular hyperechogenic ones. However large chorioangiomas are rare and complications may not always ensue. In our case the mass was large, highly vascular and fetal death with hydrops may be attributed to this as no other gross fetal anomaly or any maternal medical condition like diabetes or hypertension was detected.

The main fetal risks are non-immune hydrops, cardiomegaly, congestive cardiac failure, anaemia, thrombocytopaenia, consumptive coagulopathy, prematurity and sudden infant death. Fetal hydrops was the only finding observed in our case. The main maternal risks associated with these tumours are polyhydramnios, antepartum haemorrhage, toxaemia of pregnancy and preterm delivery. ${ }^{6}$ A large placental chorioangioma may even cause obstructed vaginal delivery as was observed in our case where there was delay in delivery of the placenta. Sudden intrauterine death can be caused by fetal congestive cardiac failure with cardiac enlargement caused by arteriovenous shunt through a placental chorioangioma causing chronic fetal hypoxia secondary to insufficient placental function or anemia. Anaemia may be secondary to blood sequestration in the tumour or fetomaternal haemorrhage. ${ }^{7}$ The other reason for sudden fetal death may be bleeding from ruptured sinusoids within the tumour. ${ }^{8}$ The prognosis is poor if fetal hydrops develops. Perinatal death rate of $30-40 \%$ has been reported due to microangiopathic hemolytic anemia, thrombocytopaenia and hydrops. ${ }^{9}$

Colour doppler imaging not only helps to differentiate chorioangioma from other lesions like degenerating fibroid, placental teratoma, vanishing twin, placental haematoma but also helps in perinatal follow up of these cases. ${ }^{10}$ Till now there are no studies to demonstrate the sensitivity and specificity of magnetic resonance imaging in distinguishing chorioangioma from other placental lesions. ${ }^{11}$ Chorioangioma have no malignant potential. Prenatal treatment by ultrasound guided interstitial laser therapy is one of the interventions to prevent complications of chorioangioma besides the use of suture ligation, bipolar cautery, microcoil embolisation and alcohol injection described in literature. ${ }^{12}$ Recent literature shows ongoing studies illustrating complexity in placental tissue growth factors, cytokines, angiogenic and anti-angiogenic factors to be responsible for multiple recurrent chorioangiomas. ${ }^{13}$

\section{CONCLUSIONS}

A routine antenatal ultrasound scan should not only screen the placental location but also the placental composition to exclude the presence of a large chorioangioma. As this tumour is associated with unfavorable effects on mother and fetus, pregnancy needs to have regular surveillance which includes serial ultrasound, Doppler studies and fetal echocardiography to detect and manage complications early and effectively for safe maternal and fetal outcome.

\section{REFERENCES}

1. Barros A, Freitas AC, Cabral AJ, Camacho MC, Costa E, Leitão H, Nunes JL.Giant placental chorioangioma: a rare cause of fetal hydrops.BMJ Case Rep. 2011 May 16;2011.

2. Norris M. Placental mass-clinically suspected chorioangioma. AJUM. 2009;12(4):30-2.
3. Sethi SK, Hemal U, Solanki RS, Bhagra A. Chorioangioma of Placenta: A Case Report. Ind J Radiol Imag. 2004;14(1):65-6.

4. James D, Steer PJ, Weiner CP, Gonik B , Crowther CA, Robson SC. High Risk Pregnancy Management Options. $4^{\text {th }}$ edition. Pennsylvania: Elsevier Saunders; 2011. p. 405.

5. GhourabS. Ultrasound in the management of chorioangioma .Saudi Medical Journal 2001;22(7):585-9. 
6. Acharya S, Pringle S. A Case of Placental Chorioangioma with the review of literature. The Internet Journal of Gynaecology and Obstetrics. 2005;5(1).

7. Duro EA. Placental Chorioangioma as the Cause of Non-Immunologic hydrops fetalis; a case report. Iran J Pediatr. 2011;21(1):113-5.

8. Batukan C, Wolfgang H, Danzer E, Bruder E, Hosli l, et al. Large Placental Chorioangioma as a Cause of Sudden Intrauterine Fetal Death Report. Fetal Diagn Ther. 2001;16:394-7.

9. Zanardini C, Papageorghiou A, Bhide A, Thilaganathan B. Giant placental chorioangioma: natural history and pregnancy outcome. Ultrasound Obstet Gynecol. 2010;35:332-6.
10. Zalel Y,Gamzu R, Weiss Y, Schiff E, Shalman B, Dolizky M, Achiron R. Role of color Doppler imaging in diagnosing and managing pregnancies complicated by placental chorioangioma. J Clin Ultrasound. 2002;30(5):264-9.

11. Kirkpatrick AD, Podberesky DJ, Gray AE, McDermott JH. Placental Chorioangioma. Radiographics. 2007;27:1187-90.

12. Lau TK, Leung TY,Yu SC,To KF, Leung TN. Prenatal treatment of chorioangioma by microcoil embolisation. BJOG. 2003;110(1):70-3.

13. Gallot D, Marceau G, Delmas HL, Vanlieferinghen P, Dechelotte PJ, Lemery D, Sapin V. The Changes in Angiogenic Gene Expression in Recurrent Multiple Chorioangiomas. Fetal Diagn Ther. 2007;22:161-8 